\title{
Intravascular Papillary Endothelial Hyperplasia
}

National Cancer Institute

\section{Source}

National Cancer Institute. Intravascular Papillary Endothelial Hyperplasia. NCI Thesaurus. Code $C 4391$.

A reactive, well-circumscribed vascular lesion. It is characterized by the formation of thin papillae projecting within the lumen of blood vessels. The papillae are lined by plump endothelial cells. Blood clots are also present. 